\title{
ANNA SKIBSKA
}

Uniwersytet im. Adama Mickiewicza w Poznaniu, Wydział Filologii Polskiej i Klasycznej, Instytut Filologii Słowiańskiej, Zakład Literatur i Języków Zachodniosłowiańskich

\section{From Signature to Stigma Cixous reads Derrida}

"Good" literary criticism, the only worthwhile kind, implies an act, a literary signature or counter-signature, an inventive experience of language, in language, an inscription of the act of reading in the field of the text that is read.

Jacques Derrida [1991: 52]

\section{Signature in constellation. Several consequences resulting from its applications and affinities}

The initial utterance clearly makes a point of departure for signature which understanding becomes - as befits Jacques Derrida - specifically hindered due to its inclination to assignation, revealed by the thinker. Such an assignation is to be treated as the occasional substitute for signature, however, with regard to the economical provenance of the first term (inscribing itself into a phenomenon of exchange), its content seems not to be so transparent. Signature is therefore juxtaposed with assignation, and such a gesture occurs on the law of co-existence as for the same root both the words come from. Thus as might be easily expected, the words are derived from signum (signare), the very strange lexeme one ought to describe as a form that turns out to be self-disrupted (or self-distorted) because

${ }^{1}$ In Archive Fever [1995: 7], Derrida himself underlines a sophisticated value of epigraph that is expressed in the following words: „To cite before beginning is to give the tone through the resonance of a few words, the meaning or form of which ought to set the stage. In other words, the exergue consists in capitalizing on an ellipsis". 
of its ambiguity which is also related to the unstable realm of signified (signifié). With accordance to the deconstructive point of view, signified - as the unprofitable and delusive heritage of the co-called metaphysics of presence - henceforth must be fathomed out through its necessary drift towards meaningless meaning that is deprived of any ultimate sense. Yet according to the canonical definition of signature itself, the main role plays the term's explicitness namely, disambiguation, radically questioned by the deconstructive reflection from which, however, the other property of signature has not been erased that is, its singularity, assumed in the conventional explanation of the term. Let me then recall its traditional understanding in light of which a signature consists of a sign or sequence of signs assumed as an explicit, singular identifier of an object, thing, or document. Signification, within its force coming from signature, opens itself up for a phenomenon of identification, and its seriously problematical status is thus revealed in the act of reading/writing of which a material evidence (in the form of signature or counter-signature) unveils a certain incommensurability between such notions like a discourse and a text. Moreover, this incommensurability is precisely reflected by disjunction of logic and rhetoric. Henceforth, in the perspective of logic, the discourse is comprehended by Derrida as "the present, living, conscious representation of a text within the experience of the person who writes and reads it" whereas the text, govern by rhetoric and exposing its formal aspects, "constantly goes beyond this representation by the entire system of its resources and its own laws" [1997: 101]. Due to this contradiction, any signature might be therefore unfolded as an effect of the clash of the discourse and the text thanks to which it does preserve its uniqueness, its own singularity, and at the very same time escapes the explicit identification. Thus the procedure of constituting of signature, non-ostentatious or almost secret, enables a departure from the totalizing system of traditional interpretation, consisting in the appropriation of the text by the reader. The reader - perceived therefore as a victim of the logical principles - turns out to be enslaved by an overwhelming power of translation that proceeds between the language of the self and the language of the Other, and unavoidably causes a disintegration of the latter. In order to secure (or to seal) its own unique idiom, spreading in the space bordered on two sides by the discourse and the text, signature imposes a necessity of development of a peculiar sense I tend to call "counter-reading". The activity of counter-reading can be (but not necessarily) crowned by counter-signature or counter-assignation, confirming a performative power of the call floating from the other writing. The above introduced strategy reveals a specific and valuable property of literature (or broader: culture), introduced by Derrida as a force of signification (or a force of literary events), and subsequently commented in the famous interview, given by the thinker to Derek Attridge. According to this commentary, one may find out that: 
The law of literature tends, in principle, to defy or lift the law. It therefore allows to think the essence of the law in the experience of this "everything to say". It is an institution which tends to overflow the institution. [1991: 36]

Experience of Being, nothing less, nothing more, on the edge of metaphysics, literature perhaps stands on the edge of everything, almost beyond everything, including itself. It's the most interesting thing in the world, maybe more interesting than the world... [1991: 43]

Thus each encounter of signature with counter-signature, assignation with counter-assignation, should be conceived as a link throughout an intriguing history of the above recalled thinking is manifested. This thinking therefore is conditioned on the ironic distance which does not content itself with a simple, nihilistic gesture of negation, in order to undermine the sphere of signifie that results in unveiling the only essence of the language, by Paul de Man called a "meaningless and chaotic matter"

The act of suspension concerning logic of the discourse opens itself up to a subtle play of interrogation that should be considered, in my opinion, as the most accurate epithet I can find to name Derrida's thinking that also renders its primal goal that is, a spectacular destabilization of metaphysical dogmatisms. Furthermore, this interrogation seems to be an only comportment one can assume while facing a transience and uncertainty of literary events, performing their "spectacle of sense" [the expression of Anna Burzyńska 2001: 326] of which fate is never possible to predict. The only response that meets requirements of the interrogation, henceforth considered as the crucial principle of the counter-reading, ought to correspond to a structure of apophatic or evasive reply whereby any counter-signature (in-the-act-of-constitution) initiates its own alternative fiction, different from the one that is promised by a signature. Moreover, the stance, consequently maintained by Derrida, is derived from the paradox conviction according to which:

There is no assured essence or existence of literature. If you proceed to analyze all elements of a literary work, you will never come across literature itself, and some traits which it shares or borrows, which you can find elsewhere too, in the other texts, be it a matter of the language, the meanings or the referents... [1991: 73]

${ }^{2}$ For de Man, the language consists of two layers: the first one regards all the rules and principles according to which one may, generally speaking, read and write that is, more or less sophisticated devices of rhetoric among of which the overriding role is attributed to irony. The negative structure of the indicated figure enables a manifestation of the second layer of the language namely, its pure matter that is deprived of any sense. For more details, see: P. de Man [1979], Allegories of Reading: Figural Language in Rousseau, Nietzsche, Rilke, and Proust, Yale University Press, New Haven; P. de Man [1986], The Resistance to Theory, University of Minnesota Press, Minneapolis; Material Events: Paul de Man and the Afterlife of Theory [2001], T. Cohen et al (ed.), University of Minnesota Press, Minneapolis. 
The interrogation does not sanction the so-called semantic emptiness - on the contrary it establishes a dynamic space wherein a permanent circulation of signs occurs, and, because of such a circulation, a thread, carried by the ultimate meanings that are always to implicate the end of thinking, may evaporate or disappear. A counter-signature therefore should be regarded as an affirmation of literary event, and, in order to remain as such, must be obliged rather to ask about this event than to reply to it in the manner of a quasi-scholar, pitilessly overwhelming statement. A genuine lesson of the counter-reading that is offered by Derrida himself one will come across if follows the thinker's reflection regarding the texts of Paul Celan or Edmond Jabés. In the Shibboleth, dedicated to the first of just mentioned authors, and concentrated on a perseverative variation concerning such notions like a date, an anniversary, a repetition, or a ring, there is recalled some self-referential utterance by Celan which I tend to recognize as a core with regard to thinking of literature, and in literature. La poésie, elle aussi, brüle nos étapes namely, "The poetry, also she, does not stop at our stops" (transl. - A. S.) - now we need to ask what an incommensurable event the poet is writing about. If I attempt to elaborate on this idea, I will have to face the problem of a poem, and its extra-ordinary situation due to its status in the language. A poem therefore stops at its own date. What does it mean then? Am I allowed to pose such a question?

Derrida's essay is inaugurated with two phenomena of which a common feature is that both of them turn out to happen only once. The thinker never hesitates to call those two themes under their "proper" names that is, a circumcision and a date ${ }^{3}$. To this must be added something else. The poet Derrida writes about always dates his poems. And, to say it again and never enough, a date happens only once. What is a poem then? With accordance to my own effort I am forced to put in understanding something that must be maintained above any intention, a poem introduces itself as a thing sanctified by its date thanks to which a very uniqueness of a lyrical signature is to be preserved. Furthermore, this date has nothing in common with knowledge/cognition, and by being above all epistemological data, it does protect a singularity of an event that occurs in poetry. This event therefore finds its fulfillment not in poetry itself but in a constant, lonely way a poem undertakes to move towards poetry. Being or remaining on such a way thwarts violence of pronouncing, and at the same time announces a festival of interrogation wherein an essence of poetry, its necessary eidos, is to be suspended or dismayed. In those questions regarding a date, which might be easily transformed

${ }^{3}$ As a matter of fact, the essay is initiated by the radical, in its brief and sharp form, utterance of which content (returning in the further parts of the text in always different constellations) seems to be designed to confuse each reader, since at the very beginning he/she has to face the following words: "One time alone: circumcision takes place but once." - J. Derrida [1992: 373], Shibboleth for Paul Celan, trans. J. Wilner, [in:] J. Derrida, Acts of Literature, D. Attridge (ed.), Routledge, London, New York. 
into questions about a signature, title, or idiom, Derrida suggests to perceive an act of dating itself as a testimony of the poet's presence in inscription. Such a presence tends to undermine a thought concerning a pure poem in matter of which the thinker discretely inscribes himself into Celan's reflection in order to write:

This radical ad absurdum, the impossibility of that which, each time once alone, has meaning only on condition of having no meaning, no ideal or general meaning, or which has meaning only so it can invoke, in order to betray it, the concept, law, or genre, is the pure poem. Now the pure poem does not exist, or rather, it is "what there isn't" (das es nicht gibt!). [1991: 385]

The above presented conviction is appropriately reinforced by some paradox regarding the initial date that is conjoined with two antithetical processes: a singular and unreadable event of poem and a repetition namely, a return, an anniversary - within them a date manifests itself, becomes readable in its idiomatic unreadability. The repetition of a date conceals its fundamental uniqueness. Derrida explains this paradox in the following words:

Like physis, a date likes to encrypt itself. It must efface itself in order to become readable, to render itself unreadable in its very readability. For if it does not annul in itself the unique marking which connects it to an event without witness, without other witness, it remains intact but absolutely indecipherable. It is no longer even what it has to be, what it will have had to be, its essence and its destination, it no longer keeps its promise, that of a date. [1991: 389-90]

Yet from this paradox structure of date something else appears, and it will unveil itself if one juxtaposes, according to the thinker's instruction, a date with an incision, both streaked with a theme of circumcision that is referred to a peculiar concept of word. A date makes an incision in the body of poem, and becomes thus its memory, its trace that indicates or recalls time and space of its singular coming into existence. "To speak of an incision or cut is to say that the poem is entered into - as Derrida added - that it begins in the wounding of its date" [1991: 393]. Considering various modalities of dating, the deconstructionist permanently regains other semantic shades of the analyzed notion, and, by this procedure, arranges a representation of affirmative aporia that any interruption in order to stop such a dissemination makes impossible. The goal of aporia should not be identified with a simple pointlessness, assumed and fingered to Derrida by his opponents, on the contrary since it does coincide with a movement that is in other words, being on its way which avoids this what in the language of logic might be expressed as a point of final arrival. All passages, being traversed by a wounded poem, are equipped, however, with a lot of such teleological dangers that lie in wait for a poem's uniqueness. Meandering between Celan's poems, the thinker cuts single signs out of them (a clock, a ring, a seal, a shibboleth) in order to stretch or prolong a situation of dating that is to turn into a constellation wherein a risk of unveiling this what is unnecessary in the essay namely, its very essence, 
becomes headed off 4 . But it simply cannot be another way since,

The cipher or the seal, the imprint of the ring, counts, perhaps more than the content of the message. As with shibboleth, the meaning of the word matters less than, let us say, its signifying form once it becomes a password, a mark of belonging, a manifestation of an alliance. [1991: 396]

A very specific event therefore, as one could hastily clarify, since it enquires about identity that might be easily assumed as a quiet, non-ostentatious motif of this beautiful and strikingly poetical essay. Derrida's signature, alike Cixous's stigma, inevitably gravitates towards reflections on a topic of Jewish identity which turns out to be something that does not exist. In the passages, dedicated to the second of the above mentioned authors, the thinker overtly joins in Jabés's considerations regarding a situation of being a Jew wherein his peculiar condition is juxtaposed with a subject called, indicated, or chosen by language. Thus the chosen one, as a submissive receiver of that convocation, encounters within himself a poet who is forced to face his double status: of being master and slave of signs at the very same time; the language, put itself at this new-born poet's disposal, transforms him into a book written by the very same poet ${ }^{5}$. The poet therefore becomes a hostage held by his own writing, its metonymy that is revealed and subsequently ruined by representation. The abyss of representation into which the poet is to tumble as a central theme of the book unavoidably means a process of painful dismaying that regards his own possibility ${ }^{6}$. By the parallel reading of

${ }^{4}$ As for the title word shibboleth, let me cite Derrida's own story: "Shibboleth, this word I have called Hebrew, is found [...] in a whole family of languages: Phoenician, Judeo-Aramaic, Syriac. It is traversed by a multiplicity of meanings, it has acquired the value of a password. It was used during or after war, at the crossing of a border under watch. The word mattered less for its meaning than for the way in which it was pronounced. The relation to the meaning or to the thing was suspended, neutralized, bracketed: the opposite one could say, of a phenomenological "epokhe" which preserves, first of all, the meaning. The Ephraimites had been defeated by the army of Jephtah; in order to keep the soldiers from escaping across the river (shibboleth also means river, of course, but that is not necessarily the reason it was chosen), each person was required to say shibboleth. Now the Ephraimites were known for their inability to pronounce correctly the shi of shibboleth, which became for them, in consequence, an 'unpronounceable name'; they said shibboleth, and, at that invisible border between shi and si, betrayed themselves to the sentinel at the risk of death. They betrayed their difference in rendering themselves indifferent to the diacritical difference between $s h i$ and $s i$; they marked themselves as unable to remark a mark thus coded" - J. Derrida [2005: 24-25], Sovereignities in Question: The Poetics of Paul Celan, T. Dutoit, O. Pasanen (ed.), Fordham University Press, Chicago.

5 "The poet is thus indeed the subject of the book, its substance and its master, its servant and its theme. And the book is indeed the subject of the poet, the speaking and knowing being who in the book writes on the book" - J. Derrida [2010: 79], Writing and Difference, trans., with an introduction and additional notes A. Bass, Routledge, London, New York.

${ }^{6}$ At the beginning of Monolingualism of the Other [1998: 2], Derrida, in the manner of circonfession (see J. Derrida [1991], “Circonfession." Jacgues Derrida, collaboration with G. Bennigton, Seul, Press, Paris; J. Derrida [1992], Jacques Derrida, trans. G. Bennington, University of Chicago 
Derrida's texts, inspired by Celan and Jabés, one can easily recognize various concurrences regarding the apophantic description of the date and the poet among of which a diagnosis of madness, conjoined with those two phenomena, strikes the most. In Livre des questions by Jabés, this madness comes from a rebel of the words inhabited by the poet, whereas in Celan's poems - due to the dual structure of the date itself that is well reflected in the following utterance: "If I say that the sense of a date opens into madness, a kind of 'Wahnsinn', this is not to move you: only to enunciate what there is it read in a date, in the injunction or chance of every reading" [1994: 29] $]^{7}$. A catastrophic dimension of this date, including any possible dating, results from its temporality corresponding to a clock that guards past. And the past constantly multiplies itself, however, it remains at risk of losing its memory, enveloped in a shroud of language. A date, called also a hallmark with regard to its ability of burning or cutting, is consequently considered in the perspective of its a priori effacing that subsequently determines the force of its signification, and unveils a secret agreement reached between Heidegger and Derrida as for a strategy of writing under erasure ${ }^{8}$. The expected efficacy that comes from this strategy is to suspend all delusive principles derived from logic of contradiction.

As we have seen, the "sense" of shibboleth (see the footnote № 3 ) is hidden in its "unpronounceable name" that directly refers to the Jewish identity, never possible to define, escaping all definitions; its lack of roots might be only juxtaposed with the poet's situation since in the both cases interrogation results from a double experience of absence and isolation.

The absence in Shibboleth is associated with a spectral character of every word ("Word is a specter", as Derrida writes), its peculiar afterlife, constantly returning in the cycle of repetitions. These repetitions grant to words their infinity, however, they also force the very same words to accept or to agree with the infinitive experience of nothingness towards which this strange institution of language perpetually drifts.

I will suggest a cut now, although to make this textual wound more painful I tend to invoke Derrida's question [1992: 391], articulated under the address of a circumcised word: "How can one write nothing?"

Press, Chicago), articulates a peculiar thought, "Yes, I only have one language, yet it is not mine", which contradictory content renders the above mentioned situation of a poet/a Jew, suffering, alike the thinker, from a "disorder of identity" [1998: 16-18], presented in the further passages of the quoted text.

7 Furthermore, with regard to the previous citation, Derrida added [1998: 10]: "I have always suspected the law, as well as language, of being mad, of being, at any rate, the unique place and the first condition of madness."

${ }^{8}$ For more details, see: M. Heidegger [1958: 80-83], The Question of Being, trans. W. Kluback, J. T. Wilde, bilingual edition, Rowman \& Littlefield, New York; G. Ch. Spivak [1997: XIV-XVIII], Translator's Preface, [in:] J. Derrida, Of Grammatology, corrected edition, trans. G. Ch. Spivak, The Johns Hopkins University Press, Baltimore, London. 


\section{Stigma, stigmatization and stigmatext}

In order to signal an event of some intellectual communion that occurs between Derrida and Cixous ${ }^{9}$, I would like to begin with a sentence which includes an idiomatic phenomenon, indicated, next to the prior term of signature, in the title of my writing. In his counter-signature, posing several questions about the poetry of Paul Celan, Derrida announces that "the date must conceal within itself some stigma of singularity if it is to last longer" [1991: 396]. Thus I am to bear witness (a reader inevitably turns into a witness) to the event of gift, the gift of stigma, of which Cixous makes an extra-ordinary use that results in the above promised phenomenon of stigmatext. One has to admit that the author of the famous The Laughter of Medusa never denies the fact that her own idiom has developed itself from Derrida's thought of diversifying signature that attempts to manifest itself as "some stigma of singularity". As we may expect, Cixous, in the very manner of her companion in writing, extends the semantic field of stigma. The stigmatext therefore ought to be conceived as a peculiar contamination, or encounter, of signature and counter-signature, wherein a singular inter-semiotic exchange takes place. Alike Derrida in The Truth in Painting, Cixous tries to articulate her own experience that springs from an intimate relationship with several paintings. Considered as stigmata, the writer assumes to be given, these paintings bite, sting, pinch, prick, pierce, cut, ravage, burn in order to stigmatize, as well as Derrida's dates, and as well as his signatures not without reason called "reminders which remain when the thematics is exhausted" [1992: 61]. One will need to recall a collection of sentences, derived from the lyrical Preface which the writer opens her Stigmata with, if we are to convince ourselves as for the burden of debt that Cixous owes to Derrida:

Stigmata are traces of a sting. Piquer in French, to prick, to sting, to pinch, pricks in order to take, in order to prick piquer steals, strikes and removes, sows, speckles signs its blows, leaves behind and takes away, annoys and excites at the same time, gives back what it takes, serves the interests of the thief and the police.

Piquer has the resources of Figaro in French: it has innumerable aptitudes and identities. One can be stung by a bug of (se piquer de) literature or philosophy as others can shoot (se piquer de) drugs. With piquer and stigmata we have what we need to explore the scene of writing.

In this volume I chose to cultivate the stigma. In the first place I take it by its roots. Its etymology. Let us follow the sti. What a stupefying multitude starting with the Greek stigma, and the Latin $s t i-$ ! Stigma sticks, stings in English. Pique in French. Sticht in German.

Stigma stings, pierces, makes holes, separates with pinched marks and in the same moment distinguishes - re-marks - inscribes, writes.

9 To penetrate this intellectual communion, one has to realise its complex origins, derived from Derrida's and Cixous's biographies, which refer to some important data; among of them the most important are two experiences: of Algeria and of Jewishness; for more details see: B. Peeters [2013], Derrida: A Biography, Polity Press, Cambridge, Malden. 
Stigma wounds and spurs, stimulates.

Stigma hallmarks, for the best and for the worst: stigmata on the body are as noble as the are ignominious, depending on whether it is Christ or the outcast who is marked.

Stigma always kills two birds with one stone. The person who is properly or figuratively stigmatized has traits of the saint (Saint Francis of Assisi) and the outlaw, of the martyr and the condemned. The sigma conveys the strongest message, the most secret message, the one that is most difficult to obey: whether good or bad, the stigmatized person is signalled out for exclusion and election. [2008: XIII]

Among the five properties, distinguished by the scholars with reference to Derrida's différance [Harvey 1986; Burzyńska 2001], there is a peculiar diversification that highlights the spatial aspect of this dynamic device of the critical reading according to which a notion's semantic field ought to be drawn aside in order to produce gaps between its various levels of meaning. As we have already seen, Cixous practices the very same strategy of diversification that significantly reinforces an ambivalence of stigma which excludes and elects, spurs and stimulates at the same time. Due to this ambivalence, something like an ultimate sense of stigma becomes postponed, for its mute or suspended meaning dwells exactly in those gaps. Moreover, a stigma constitutes a call for event, that is in other words, a call for stigmatext in which borderlines an experience of pain (since stigma wounds) allies itself with a spirit of invention (since it stimulates). Such an alliance subsequently initiates an acute or biting diacritics that simultaneously cuts up and establishes the writing self's idiom, and that turns out to be conjoined with an affirmation of expelling from interior of the self, an acceptance of exile that begins in a text: wounded or marked alike a poem together with its date.

Cixous's Preface to Stigmata remains to a certain extent in a mirror relation to the texts I have commented in the first part of my essay because it does reflect the structure of play, arranged by Derrida, and despite the presentation of different themes and motifs they are still streaked with an indissoluble analogy to the signatures created by the author of The Margins of Philosophy. The prophet Elijah, recalled by Derrida in the end of Shibboleth with regard to the phenomenon of circumcision and derived from it an genuine concept of circumcised word (in the Hebrew world, Elijah is a patron of this ritual), and also commented by Cixous in the portrait dedicated to her precursor $[2001]^{10}$, in Stigmata [2008: XIII-XIV] is supplemented by the figure of Job whose ambivalence is illuminated in the following passage:

${ }^{10}$ In Portrait of Jacques Derrida as a Young Jewish Saint [2001: 21-22], besides the quotations from Shibboleth and "Circonfession" one may come across such an intimate writing of Cixous herself: "Elijah, the name of the one who gets carried away, elevated over the head of his pupil Elisha who also aspired to Elysium, Elie (2 Kings), Elie the name he [Derrida - A. S.] has never borne, his phantom name but in French - for if it came late, Elie, he who receives it - one no longer knows who receives whom in the ancient circus of hospitality - makes the most of its letters and imaginative effects in French." 
According to banishing judiciary customs, the branded criminal, the criminal marked with the red iron is comparable to someone with smallpox, who is marked as one of the guilty. When marked, the innocent person is 'guilty'. And this is one of the tricks of our psychic cruelty: the victim is designated, distinguished, shamed, guilty. Every victim is accused, this is Job's complaint, Job the accused-accuser.

Cixous writings, as well as Derrida's texts, like to situate themselves in the explicit or implicated neighborhood of Kafka's works, since his highly ambivalent words, originated from the power of ironic corrections, perfectly meet the deconstructive expectations. Kafka is present in the essay written for Celan, one of his aphorisms is recalled in the text on Jabés ("We are nihilist thoughts in the brain of God" [2010: 82]) ${ }^{11}$, not to mention the writing devoted to Kafka himself (the well known Before the Law [2002]). It will not therefore be a surprise if I say that the author of The Castle also returns in Cixous's Preface [2008: XIV] wherein one may encounter with such a self-referential confession:

(The author or) The artist is the gardener of the thorn bush in spite of himself. He has been place and then raised in a thorn bush, and even as, like Kafka's character, he asks the Guardian of the Park to quickly bring help, he is already thinking about what he will write with one of these sharpened gorses, if he survives the awful accident. Sometimes he does not survive.

In the further parts of Preface, there are also other indications, consequently maintained in the manner of confession, that suggest a strong influence of signature, its extra-ordinary pressure put on counter-signature. That influence intensifies the impression of hospitality, of exchange that from time to time unveils an intriguing transfer of signs between these two assignations which occur but once:

The stigma is the trace of a nail's sting. The mark of the pointed object. The stigma is a scar that is difficult to efface. The stigma resist being worn down. The hole enters into my skin. The scar adds, the stigma digs, excavates.

I want stigmata. I do not want the stigmata to disappear. I am attached to my engravings, to the stings in my flesh and my mental parchment. I do not fear that trauma to maintain and to reanimate traces.

Traumatism as an opening to the future of the wound is the promise of the text.

As is well known, the themes of psychosomatic space (evoked by the above cited fragment) already belong to the standard repertoire of this, what, thanks to Cixous, we have familiarized with under the term of écriture feminine (it generates a phenomenon of somatexts, written by Cixous, Kristeva, Irigaray $)^{12}$, a stra-

11 The aphorism, quoted by Derrida, ought to be expanded by another one, also by Kafka, especially that it inscribes itself in the issue of interrogation: "Earlier, I didn't understand why I got no answer to my question, today I don't understand how I presumed to ask a question. But then I didn't presume, I only asked." - F. Kafka [2006: 36], The Zürau Aphorisms, trans. M. Hofmann, with an introduction and afterword R. Calasso, Harvill Secker, London.

${ }^{12}$ For more information on a somatext, see: U. Śmietana [2003], Od écriture feminine do somatekstu. Ciało w dyskursie feministycznym, "Przegląd Filozoficzno-Literacki", nr 1 (3). 
tegy which itself originates from Derrida's différrance, for above all it gives the otherness the floor. From the perspective of écriture feminine, the otherness is manifested by a unique singularity of soma that situates itself beyond the discursive practices that is in other words, beyond their coherence, order, logic, imposed by the rational model of cognition and the communicative conventions.

In the final passages of Preface, one more scene is to unveil in order to sustain the ambivalence of stigma:

Stigma is gendered masculine in French.

But now I discover with pleasure a supplementary trick that Stigma plays on us:

In another reign, in another scene, that of vegetation, stigma is not a sign of destruction, of suffering, of interdiction. On the contrary, the stigma is a sign of fertilization, of germination.

Stigma is a part of the pistil, the female parts of the flower, when the male pollen germinates. The stigma is a little magic uterus. In the cavity resurrection is hatched.

What is dead and what will live share the same bed. Tomb-cradle: another definition of Stigma.

This play, engaging the cycle of vegetation, in which a funeral atmosphere is streaked with a celebration of birth, resembles a clockwise movement of anniversary and a return of a date, being effaced in the ring about which informs us the author of Writing and Difference. As for the motif of funeral that directly refers to death and announces absence (gained in/by a text), Derrida makes use of a crypt, replaced by Cixous with a tomb ${ }^{13}$, nevertheless, in both cases these two words might be conceived as the metonymies of body that lives and dies only once. For that reason, it has to settle into writing, take root or enter into textual ashes which are to testify its absent presence (or present absence) in the mutual relationship of signature and counter-signature. Furthermore and still for the very same reason, the contradiction between a tomb and a cradle must be annihilated, and by such a gesture of annihilation, a stigmatext loses its identity in order to save its idiom, of tomb-cradle, in the remnants of unspeakable, of unpronounceable. Thus the mission of a form, invented by Cixous, explicates its paradox existence. Due to this, the very last utterance I wish to quote announces that "Each Stigmatext is the portrait of a story attacked from all sides, that attacks itself and in the end gets away" [2008: XVI].

${ }^{13}$ The corporeal metonymies of a crypt and of a tomb also reveal an intense fascination with the formal aspect of signs, displayed by Derrida and Cixous. In The Truth in Painting [1992: 191], instead of a crypt there is a coffin of which theme is borrowed by Derrida from the work of Titus-Carmel: "What can one desire of a coffin if not to have it for one's own, to steal it, to put oneself inside and see oneself in it, lie or give birth in it [...], preferably with the other, this being another way of neutralizing it, of calming one's own terror, of dealing with alterity [...]? But what can one desire of a coffin except that it remain where it is, at a distance, to one side [à l'écart] - reproducing the écart, insisting to exhaustion - except that it remain the other's? The two desires are not contradictory, nor are the two gestures thus induces. They are always negotiating kenosis, they deal with each other for the dead man." 


\section{Bibliography}

Burzyńska A. [2001], Dekonstrukcja i interpretacja, TAiWPN Universitas, Kraków.

Cixous H. [2001], Portrait of Jacques Derrida as a Young Jewish Saint, transl. B. Bie Brahic, Columbia University Press, New York, Chichester, West Sussex.

Cixous H. [2008, first pub. 1998], Stigmata. Escaping Texts, with a foreword J. Derrida and a new preface by the author, Routledge, London, New York.

Derrida J. [1992], Acts of Literature, with an introduction, D. Attridge (ed.), Routledge, London, New York.

Derrida J. [1995], Archive Fever. A Freudian Impression, transl. E. Prenowitz, The University of Chicago Press, London, Chicago.

Derrida J. [1991], “Circonfession." Jacques Derrida, collaboration with G. Bennington, Seuil Press, Paris.

Derrida J. [1992], Jacques Derrida, trans. G. Bennigton, University of Chicago Press, Chicago.

Derrida J. [1998], Monolingualism of the Other; or, The Prosthesis of Origin, transl. P. Mensah, Stanford University Press, Stanford, California.

Derrida J. [corrected ed. 1997, first American ed. 1976], Of Grammatology, transl., introduction G. Ch. Spivak, The Johns Hopkins University Press, Baltimore, London.

Derrida J. [1994], Shibboleth for Paul Celan, trans. J. Wilner, [in:] Word Traces: Readings of Paul Celan, A. Fioretos (ed.), The Johns Hopkins University Press, Baltimore, London.

Derrida J. [2005], Sovereignties in Question: The Poetics of Paul Celan, T. Dutoit, O. Pasanen (eds.), Fordham University Press, Chicago.

Derrida J. [1992], The Truth in Painting, transl. G. Bennington, I. McLeod, The University of Chicago Press, Chicago.

Derrida J. [2010, first English ed. 1978], Writing and Difference, transl., introduction and additional notes A. Bass, Routledge, London, New York.

Harvey I. [1986], Derrida and the Economy of "Différance", Bloomington.

Heidegger M. [bilingual ed. 1958], The Question of Being, transl. W. Kluback, J. T. Wilde, Rawman \& Littlefield, New York.

Kafka F. [2006], The Zürau Aphorisms, transl. M. Hofmann, introduction and afterword R. Calasso, Hervill Secker, London.

Peeters B. [2013], Derrida: A Biography, Polity Press, Cambridge, Malden.

Śmietana U. [2003], Od écriture feminine do somatekstu. Ciało $w$ dyskursie feministycznym, „Przegląd Filozoficzno-Literacki”, nr 1 (3). 